\title{
Soil Nutrients Can Influence Exotic Species Richness in Urban Areas: A Case Study from the City of Kolkata
}

\author{
Seemanti Chatterjee, Anjana Dewanji ${ }^{*}$ \\ Agricultural and Ecological Research Unit, Indian Statistical Institute, Kolkata, India \\ Email: *anjdew@gmail.com
}

How to cite this paper: Chatterjee, S. and Dewanji, A. (2019) Soil Nutrients Can Influence Exotic Species Richness in Urban Areas: A Case Study from the City of Kolkata. American Journal of Plant Sciences, 10, 2052-2069.

https://doi.org/10.4236/ajps.2019.1011145

Received: October 9, 2019

Accepted: November 25, 2019

Published: November 28, 2019

Copyright $\odot 2019$ by author(s) and Scientific Research Publishing Inc. This work is licensed under the Creative Commons Attribution International License (CC BY 4.0).

http://creativecommons.org/licenses/by/4.0/

c) () Open Access

\begin{abstract}
Urbanization contributes to extensive land use changes and environmental degradation which may influence changes in soil properties. These abiotic changes may aggravate invasions and favour the distribution and number of invasive species in urban areas which could negatively impact biodiversity. This case study was, therefore, undertaken in the metropolitan city of Kolkata to assess the existing plant species richness (both native and exotic) and to determine the relative role of some soil physico-chemical parameters on species richness. Plant species were recorded and soil samples were collected from each study site. The total species richness ranged from 4 to 25 with $50 \%$ of sites having a median number of 11 species. The presence of at least 3 or more invasive species was observed in $>80 \%$ of sites. The mean and median values of soil parameters showed considerable variation in soil properties between sites. Urban soils had elevated $\mathrm{pH}$ values and higher available $\mathrm{N}, \mathrm{P}$ and $\mathrm{Ca}$. Soil available $\mathrm{N}$ appeared to be significantly correlated with both total species and exotic (including invasive) species richness while available phosphorus showed significant correlation with only exotic species richness. The GLM Poisson log-linear models showed a significant positive relationship of soil $\mathrm{N}$ with total species richness and exotic richness including invasive species richness in the study area.
\end{abstract}

\section{Keywords}

Urban Area, Species Richness, Soil Physico-Chemical Parameters

\section{Introduction}

Urban areas, which are rapidly increasing in developing countries like India, not 
only contribute to the world's population [1] but are also associated with extensive land use changes and environmental degradation [2] [3] [4]. The surface soil in these areas get mixed and is covered by artificial impervious surfaces, due to the mechanical and/or chemical disturbance associated with urbanization, which may cause an irreversible loss of many soil properties and functions [5]. Urban soils contain large pools of carbon, nitrogen and other elements which help to support plant growth and sustain biogeochemical cycles [6]. They also provide an array of ecosystem services like reducing bioavailability of pollutants, habitats for soil and plant biota, microclimate regulation and food production [7] [8] [9]. Hence, any change in soil properties may eventually affect nutrients directly or indirectly endangering soil and plant biodiversity which may eventually lead to environmental changes on a larger scale [10] [11] [12].

The indirect effects of urbanization also involve changes in the biotic and abiotic environment which include the urban heat island effect [13] [14] atmospheric deposition of various pollutants [15] [16] as well as the introduction of exotic species [17]. The rate of atmospheric nitrogen deposition, which has more than doubled over the past century, is one of the main causes of global biodiversity loss and this is especially threatening for tropical regions where the most diverse biota occur [18] [19] [20] [21]. Furthermore, global environmental changes may aggravate plant invasions which have been found to be highly responsive to rising temperature and altered precipitation that may favour the distribution and number of invasive species [22]. Precipitation has been found to be one of the key factors shaping the richness of regional invasive species in India. For example, the richness of naturalized invasive species was found to be positively related to states receiving higher amounts of precipitation [23] while the probable distribution of Lantana camara and Cassia tora towards northern and north-eastern directions has been demonstrated to be due to changes in moisture availability [24]. The affinity of invasive species towards warmer, drier and wet places was reported in a study by Tripathi et al. [25], where a significant correlation of invasive species with anomalies in both temperature as well as precipitation was observed.

In addition to climatic variables which influence plant communities at the regional scale [26], the use of edaphic predictors have also been found to significantly enhance the accuracy of model predictions for plant invasions [27]. Variation in soil properties such as clay content, $\mathrm{pH}$ and soil $\mathrm{N}$ correlated with a two to four-fold change in the growth of invasive grasses [28]. On the contrary, inconsistent results have also been reported where the physio-chemical properties of soil could not explain the presence of weeds in urban environments [29] while there was no effect of nutrient enrichment on invasion success [30].

With half of the world's population now residing in cities [9], where people and nature coexist in close proximity, the important role of nature in promoting human health and psychological well-being is increasingly being recognized [31] [32] [33]. In view of the rapid pace of urbanization and the continuing decline in biodiversity, it thus becomes important to record the species richness of vegeta- 
tion as well as the soil physico-chemical properties especially in the developing cities of tropical regions which can act as hubs for spread of exotic species [34]. This study was, therefore, undertaken in the metropolitan city of Kolkata to assess 1) the species richness (both native and exotic) within this area and 2) to determine the relative role of some physico-chemical factors in influencing the existing plant species richness.

\section{Materials and Methods}

\subsection{Study Area}

Greater Kolkata is an urban agglomeration of the city of Kolkata, situated in West Bengal, India. It is surrounded by rural areas [35] and is located between $22^{\circ} 019^{\prime} \mathrm{N}$ to $23^{\circ} 001^{\prime \prime}$ North Latitudes and $88^{\circ} 004^{\prime} \mathrm{E}$ to $88^{\circ} 033^{\prime \prime}$ East Longitudes, covering an area of $1851 \mathrm{~km}^{2}$ [36]. The urban built-up land constitutes $54.2 \%$ of the current total area and residential use contributes to about $31.2 \%$ of the total area [37]. Kolkata has a tropical climate with annual mean temperature of $26.8^{\circ} \mathrm{C}$ and monthly mean temperature of $19^{\circ} \mathrm{C}-30^{\circ} \mathrm{C}$ [37], with high precipitation during the monsoon months (e.g. June to September).

\subsection{Sampling Protocol and Estimation of Soil Parameters}

Twenty one terrestrial sites, equally distributed on both sides of the Hooghly River, could be sampled for this case study. Within each site, 4 replicates of 1 sq. meter quadrats were randomly placed on a patch of vegetation and species present in the quadrat were noted for estimating species richness. Plants were later identified and the numbers of native species, exotic species and the overall species richness for each site were recorded. Subsequently, soil samples were collected from each quadrat (a composite of 3 subsamples) with a hand held push probe from a depth of $10 \mathrm{~cm}$ from the surface, packed in polythene bags and transported to the laboratory for subsequent analysis. In the laboratory, the soil samples were air dried, homogenized using a mortar and pestle, sieved through a $2 \mathrm{~mm}$ mesh and stored for further analysis Soil $\mathrm{pH}$ and electrical conductivity (EC) were determined using the methods described in AOAC [38]. Available nitrogen $(\mathrm{N})$ content of soil was determined by steam distillation using the Kjeldahl semi-automatic analyzer while available phosphorus $(\mathrm{P})$ was determined by the spectrophotometric method of Olsen et al. [39]. The potassium (K) and calcium $(\mathrm{Ca})$ contents were analyzed using the flame photometric method [40]. Soil organic carbon (OC) was analyzed using the dichromate oxidation technique [41].

\subsection{Statistical Analysis}

The Likelihood Ratio test for equality of means was conducted to examine differences in mean number of richness between native and exotic species distributions. Correlation coefficients were used to assess the strength and direction of the linear relationships between species richness (total species, total exotics, total 
invasives and total natives) and the soil physico-chemical variables. Transformations were performed when necessary to satisfy assumptions. Generalized linear models (GLMs) with Poisson regression were used, assuming logarithmic relationships (the link function) between explanatory (X) and response variables $(\mathrm{Y})$, to study the relationship between the significant soil parameters and plant species richness. Three Poisson log-linear regression models were used to investigate the effect of soil parameters on species richness.

$$
\begin{array}{ll}
\text { Model 1 } & Y_{1} \mid X_{N} \sim \operatorname{Poisson}\left(\mathrm{e}^{\alpha+\beta_{1} X_{N}}\right) \\
\text { Model 2 } & Y_{2} \mid X_{N}, X_{P} \sim \operatorname{Poisson}\left(\mathrm{e}^{\alpha+\beta_{1} X_{N}+\beta_{2} X_{P}}\right) \\
\text { 2a } & Y_{2} \mid X_{N}, X_{\ln P} \sim \operatorname{Poisson}\left(\mathrm{e}^{\alpha+\beta_{1} X_{N}+\beta_{2} X_{\ln P}}\right) \\
\text { Model 3 } & Y_{3} \mid X_{N} \sim \operatorname{Poisson}\left(\mathrm{e}^{\alpha+\beta_{1} X_{N}}\right)
\end{array}
$$

where

$Y_{1}=$ No. of total species; $Y_{2}=$ No. of total exotics; $Y_{3}=$ No. of total invasive; $X_{N}=$ Soil available nitrogen $(\mathrm{mg} / \mathrm{kg}) ; X_{P}=$ Soil available phosphorus $(\mathrm{mg} / \mathrm{kg})$ and $X_{\ln P}=$ Soil available phosphorus - $\ln$ transformed (mg/kg).

All the statistical analyses were carried out using R version 3.2.

\section{Results and Discussion}

\subsection{Species Richness in Urban Areas}

The overall distribution of species richness from selected sites, provided in Table 1 , shows a wide variation in total species richness ranging from 4 to 25 within the city of Kolkata. The median values, which are more robust to outliers than the mean, were 11, 5 and 5 for total species richness, native species and exotic species numbers respectively. When the sites were judged for richness patterns based on the median values, $50 \%$ of sites showed total species richness $\geq 11$ indicating a good number of species in many urban sites. Similarly, for both native and exotic species, more than $50 \%$ of sites supported greater number of species than the observed median value of 5 . The Likelihood ratio test revealed no significant difference between mean numbers of native and exotic species richness $(s=0.214 ; p=0.643)$. Urban areas, with heterogeneous patches of habitats coupled with human introduction of exotic species, often support high numbers of species [15] [42].

Among the exotics, the majority were invasive species (median value of $\geq 3$ in sites) that can spread over long distances from parent plants and can often cause ecosystem damage [43]. The presence of at least 3 or more invasive species in $>80 \%$ of sites $(n=17 / 21)$, as is evident from the table, denotes the presence of multiple invaders in most sites. Urban landscapes are highly altered by development and human activities [7] which is one of the prime reason for the increasing prevalence of exotic plant species (many among which are invasive) that are being reported from cities [44]. Negative impacts of plant invasions on soil 
Table 1. Distribution of plant species richness in Kolkata.

\begin{tabular}{|c|c|c|c|c|c|c|}
\hline & & Minimum & Maximum & Mean \pm SD & Median & $\begin{array}{c}\text { Presence in sites } \\
\text { based on median } \\
\text { values }\end{array}$ \\
\hline $\begin{array}{c}\text { Total species } \\
\text { richness }\end{array}$ & & 4 & 25 & $11 \pm 4$ & 11 & $\begin{array}{l}11(\mathrm{n} \geq 11) \\
10(\mathrm{n}<11)\end{array}$ \\
\hline $\begin{array}{c}\text { Total native } \\
\text { species richness }\end{array}$ & & 2 & 15 & $6 \pm 3$ & 5 & $\begin{array}{c}15(\mathrm{n} \geq 5) \\
6(\mathrm{n}<5)\end{array}$ \\
\hline \multirow{2}{*}{$\begin{array}{c}\text { Total exotic } \\
\text { species richness }\end{array}$} & All exotics & 2 & 10 & $5 \pm 2$ & 5 & $\begin{array}{l}12(\mathrm{n} \geq 5) \\
10(\mathrm{n}<5)\end{array}$ \\
\hline & $\begin{array}{c}\text { Only } \\
\text { Invasives }\end{array}$ & 2 & 9 & $4 \pm 2$ & 3 & $\begin{array}{c}17(\mathrm{n} \geq 3) \\
4(\mathrm{n}<3)\end{array}$ \\
\hline
\end{tabular}

properties and processes [45] have been reported from both natural and managed environments [46] [47] [48].

\subsection{Urban Soil Physico-Chemical Properties}

The artificial surface layer of soil that is distributed in urban area and suburbs is physically disturbed, chemically polluted and spatially heterogeneous since it is highly influenced by anthropogenic activity [9] [49] [50]. Some of the key agents of urbanization that may alter soil physical and biological properties are housing, commerce, traffic, construction and waste, amongst others [51] [52] which result in compacting, crushing and sealing of urban soils [53]. Ecosystem services provided by soil may be severely impacted due to degradation caused by industrial activity [54] while contamination of urban soils by heavy metals may endanger biota as well as human health [55] [56] [57]. However, microorganism habitat and carbon sequestration services may be enhanced in urban soils [6] [58] [59] [60].

The soil physico-chemical parameters determined for the investigated sites are reported in Table 2 which showed wide variation between sites. Soil $\mathrm{pH}$ ranged from 6.6 to 9.4 with $90 \%$ of sites having alkaline $\mathrm{pH}$. Urban soils with elevated $\mathrm{pH}$ values have been widely reported [10] [50] [61] [62] which could mainly be related to the release of alkaline leachates from calcareous materials in cement, concrete, mortar, and atmospheric particulate deposition [63] [64]. Soil pH can influence many soil chemical processes that determine the behaviour of nutrients and contaminants which can thereby influence availability of nutrients for plant growth [65]. For example, changes in soil $\mathrm{pH}$ can influence the critical concentrations of heavy metal toxicity in both plants and microorganisms [66]. Conductivity, which is a measure of ions present in solution, varied from $39.3 \mu \mathrm{s}$ to $1151.7 \mu$ s among the sites.

The soil organic carbon content is a key constituent that dictates the soil physical and nutrient status e.g., water holding capacity and storage of nutrients (mainly N). Values of organic carbon ranged from $4.87 \mathrm{~g} / \mathrm{kg}$ to $26.22 \mathrm{~g} / \mathrm{kg}$ in the 
Table 2. Analysis of soil physico-chemical properties in Kolkata $(n=21)$.

\begin{tabular}{cccccc}
\hline & Minimum & Maximum & Mean \pm SD & Median & CV\% \\
\hline $\mathrm{pH}$ & 6.6 & 9.4 & $7.9 \pm 0.6$ & 7.9 & 8.1 \\
Conductivity $(\mu \mathrm{s})$ & 39.3 & 1151.7 & $346.7 \pm 329.5$ & 216.0 & 95.0 \\
Organic Carbon $(\mathrm{g} / \mathrm{kg})$ & 4.87 & 26.22 & $11.98 \pm 6.37$ & 10.13 & 53.12 \\
Available N $(\mathrm{mg} / \mathrm{kg})$ & 64.03 & 214.42 & $121.76 \pm 34.55$ & 113.31 & 28.38 \\
Available P $(\mathrm{mg} / \mathrm{kg})$ & 11.38 & 337.87 & $131.76 \pm 93.05$ & 109.49 & 70.62 \\
$\mathrm{~K}(\mathrm{mg} / \mathrm{kg})$ & 63.72 & 493.03 & $207.76 \pm 133.17$ & 144.97 & 64.10 \\
$\mathrm{Ca}(\mathrm{mg} / \mathrm{kg})$ & 1218.4 & 3450.8 & $2363.6 \pm 578.8$ & 2412.9 & 24.5 \\
\hline
\end{tabular}

studied sites. Higher values $(40.08 \mathrm{~g} / \mathrm{kg})$ of soil organic carbon have been reported from industrial sites while lower values $(8.24 \mathrm{~g} / \mathrm{kg})$ were found in suburban areas [6] [67]. Reduced carbon pool in microbial biomass due to soil compaction and decreased fertility of soils under heavy metal contamination are some of the factors that can prevent carbon accumulation in soil while enrichment may occur as a result of high carbon dioxide content in air, greater productivity of vegetation due to elevated temperature and reduced mineralization of plant residues under the influence of contamination with heavy metals [6] [62]. Soil contamination with coal waste is a problem in many Asian countries. Even in metropolitan cities in India, the majority of poor households continue to use cheap solid fuels like coal or charcoal [68] which may contaminate the soil.

The range values of available $\mathrm{N}, \mathrm{P}$ and $\mathrm{K}$ in soil samples within the investigated area were similar to those reported from other urban areas [61], although the mean available $\mathrm{N}(121.76 \mathrm{mg} / \mathrm{kg})$ and $\mathrm{P}(131.76 \mathrm{mg} / \mathrm{kg})$ were relatively higher. Soil nutrient contents were reported to be higher in urban areas [69] and a significantly higher $\mathrm{P}$ and $\mathrm{K}$ concentrations were observed in soils from industrial and residential city areas as compared to those from urban unmanaged forests [10]. Industrial activity and motor vehicles also release reactive nitrogen to the atmosphere through the combustion of fossil fuels and other processes to form nitrous oxides [19] which subsequently get transferred to the soil surface either as dry or wet depositions [70]. Pollutants from untreated sewage, domestic waste and excessive fertilizer applications could all contribute to $\mathrm{N}$ and $\mathrm{P}$ accumulation in urban and suburban soils [71] [72]. Furthermore, urban soil nitrogen and phosphorus can be desorbed from soils and excessive environmental inputs can cause freshwater eutrophication [73] [74]. As essential nutrients for biota, the levels of N, P and $\mathrm{K}$ in urban soils have implications for urban plant growth. High phosphorus appeared to inhibit species richness while intermediate levels of potassium appeared beneficial to diversity levels in a study on the relationships between species diversity and soil conditions in two created urban meadows sites [75]. All sites exhibited high levels of the secondary nutrient $\mathrm{Ca}$, ranging from 1218.4 to $3450.8 \mathrm{mg} / \mathrm{kg}$, which were similar to those reported in China [61]. Ca is a major component of urban construction materials (i.e., ce- 
ment and concrete) and high levels of Ca near roadside and residential areas increases the level of extractive $\mathrm{K}$ which is further catalysed by high soil $\mathrm{pH}$ [61].

Compacted and polluted soils, resulting from construction and infrastructure development of urban landscapes [51], could also influence the soil organic matter pool which has a faster turnover rate due to a much reduced mean residence time (5 years) in moist tropical areas compared to 9 - 14 years in temperate regions [76]. Changes in soil organic content may affect microbial activity in soil which is a key component of soil fertility [77]. Under urban conditions, the biogeochemical cycles of $\mathrm{C}$ and $\mathrm{N}$ are also affected [78] [79]. All this could influence the variation in nutrient content observed not only in urban and suburban soils [80] but also within different sites in urban areas [67].

\subsection{Soil Physico-Chemical Properties and Species Richness}

Soil physiochemical properties may affect plants directly through modification of biomass [81] [82] or indirectly through microbial community structure [83] [84]. All these, in turn, may induce changes in organic matter decomposition and other soil processes, and thus, in concentrations of total and available nutrients in soil [85]. Correlation coefficients, which reflect the linear relationship between the physicochemical properties of soil and plant species richness (total, native and exotics), were hence computed and have been reported in Table 3. Available $\mathrm{N}$ was significantly correlated with total species and exotic (including invasive) species richness while available phosphorus showed significant correlation with only exotic species richness, though not with invasive species richness. Both nitrogen and phosphorus enrichment are known to impact plant diversity globally since growth of plants in terrestrial ecosystems is often limited by the availability of $\mathrm{N}$ or $\mathrm{P}$ [86] [87] [88]. Increased soil $\mathrm{N}$ depositions can affect plants due to changes in $\mathrm{pH}$ and nutrient supply ratios [89] while soil $\mathrm{P}$ can also limit primary production of individual plants by limiting elements to terrestrial vegetation and can play an essential role in plant community assembly [90].

The GLM Poisson log-linear models provided in Table 4 show a significant positive relationship of soil $\mathrm{N}$ with total species richness (Model $1, \mathrm{z}=0.006, p=$ 0.002 ), exotic richness (Model 2, $\mathrm{z}=0.033, p=0.013$ ) as well as with invasive species richness (Model 3, $\mathrm{z}=0.035, p=0.002$ ). Soil $\mathrm{P}$ showed a significant relationship only with exotic richness for natural logarithms of $\mathrm{P}$, as shown in Model $2 \mathrm{a}(\mathrm{z}=0.982, p=0.040)$. Previous studies have shown that exotic plants have benefitted more than native species with enhanced soil nutrients (mainly $\mathrm{N}$ ) in different ecosystems [91] [92] [93] [94] [95]. Soil $\mathrm{N}$ also appeared to be the most important predictor variable responsible for promoting species richness in this rapidly urbanizing study area.

It has been shown that alterations mediated by invasive exotic plants on soil $\mathrm{N}$ cycles have helped these highly competitive species maximize their invasiveness [96] [97] [98] [99] [100]. For example, the ability of plants to alter $\mathrm{N}$ cycles within ecosystems and rapidly uptake $\mathrm{N}$ has been reported for cheat grass (Bromus tectorum L.), one of the most significant plant invaders in western US [101] 
Table 3. Pearson's correlation between physico-chemical properties of soil and plant species richness.

\begin{tabular}{|c|c|c|c|c|c|c|c|c|}
\hline \multirow{3}{*}{$\begin{array}{c}\text { Soil physico-chemical } \\
\text { parameters }\end{array}$} & \multirow{2}{*}{\multicolumn{2}{|c|}{$\begin{array}{l}\text { Total species } \\
\text { richness }\end{array}$}} & \multirow{2}{*}{\multicolumn{2}{|c|}{$\begin{array}{c}\text { Total native } \\
\text { species richness }\end{array}$}} & \multicolumn{4}{|c|}{ Total exotic species richness } \\
\hline & & & & & \multicolumn{2}{|c|}{ All exotics } & \multicolumn{2}{|c|}{ Only invasives } \\
\hline & $R$ & $p$ & $R$ & $p$ & $R$ & $p$ & $R$ & $p$ \\
\hline $\mathrm{pH}$ & -0.263 & 0.250 & -0.308 & 0.175 & -0.134 & 0.564 & -0.094 & 0.685 \\
\hline Conductivity $(\mu s)$ & -0.369 & 0.100 & -0.363 & 0.106 & -0.277 & 0.225 & -0.165 & 0.476 \\
\hline Organic Carbon (g/kg) & 0.090 & 0.700 & -0.071 & 0.761 & 0.269 & 0.238 & 0.182 & 0.430 \\
\hline Available N (mg/kg) & $0.509^{*}$ & 0.019 & 0.325 & 0.150 & $0.604^{* *}$ & 0.004 & $0.637^{* *}$ & 0.002 \\
\hline Available P (mg/kg) & 0.336 & 0.136 & 0.184 & 0.424 & $0.438^{*}$ & 0.047 & 0.359 & 0.110 \\
\hline $\mathrm{K}(\mathrm{mg} / \mathrm{kg})$ & -0.123 & 0.595 & -0.258 & 0.259 & 0.083 & 0.721 & 0.028 & 0.905 \\
\hline $\mathrm{Ca}(\mathrm{mg} / \mathrm{kg})$ & -184 & 0.424 & 0.259 & 0.257 & 0.039 & 0.867 & 0.101 & 0.664 \\
\hline
\end{tabular}

$R$ : coefficient of correlation; $p$ : significance; ${ }^{\star} p<0.05 ;{ }^{* *} p<0.01$.

Table 4. Coefficient estimates and significance results from log-linear Poisson regression analysis using GLM for number of total species and invasive species in relation to soil nitrogen (Model 1 and 3) as well as for numbers of exotic species in relation to soil nitrogen and phosphorus (Model 2 and Model 2a).

\begin{tabular}{|c|c|c|c|c|c|c|}
\hline & $\begin{array}{l}\text { Response } \\
\text { variables }\end{array}$ & $\begin{array}{l}\text { Predictor } \\
\text { variables }\end{array}$ & $\begin{array}{c}\text { Estimate } \\
(\mathrm{z})\end{array}$ & Std. Error & t value & $\operatorname{Pr}(>|t|)$ \\
\hline \multirow[t]{2}{*}{ Model 1} & $\begin{array}{c}\text { Total species } \\
\text { richness }\end{array}$ & Intercept & 1.864 & 0.278 & 6.719 & $1.83 \mathrm{e}-11^{\star \star *}$ \\
\hline & & Nitrogen & 0.006 & 0.002 & 3.037 & $0.002^{* *}$ \\
\hline \multirow[t]{3}{*}{ Model 2} & & Intercept & 0.128 & 1.419 & 0.090 & 0.929 \\
\hline & $\begin{array}{l}\text { Total exotic } \\
\text { richness }\end{array}$ & Nitrogen & 0.033 & 0.012 & 2.769 & $0.013^{*}$ \\
\hline & & Phosphorus & 0.006 & 0.004 & 1.480 & 0.1561 \\
\hline \multirow[t]{3}{*}{ Model 2a } & & Intercept & -3.129 & 2.046 & -1.529 & 0.1437 \\
\hline & $\begin{array}{l}\text { Total exotic } \\
\text { richness }\end{array}$ & Nitrogen & 0.029 & 0.011 & 2.623 & $0.0173^{*}$ \\
\hline & & Ln Phosphorus & 0.982 & 0.444 & 2.212 & $0.040^{*}$ \\
\hline \multirow[t]{2}{*}{ Model 3} & $\begin{array}{c}\text { Invasive species } \\
\text { richness }\end{array}$ & Intercept & -0.362 & 1.214 & -0.299 & 0.768 \\
\hline & & Nitrogen & 0.035 & 0.009 & 3.606 & $0.002^{* *}$ \\
\hline
\end{tabular}

Model significant at ${ }^{*} p<0.05$ level.

as well as for W. trilobata for its successful invasion in China [102]. Some broad-scale studies have also found positive relation between spatial patterns of cheat grass abundance and levels of soil P [103]. Environmental variability in soil nutrient availability (as a consequence of increased fluctuations in extreme events e.g. flooding, droughts, heat waves, fires) was found to strongly promote the invasion success of the Japanese knotweed (Fallopia spp.) and possibly of many other invasive plants [104].

Increased soil $\mathrm{N}$ availability can lead to enhanced biomass production by invasive plants which can affect their growth and competitive advantage over na- 
tives due to the higher resource acquisition and lower nutrient requirements of the invaders [105], thereby intensifying invasions [106]. The invasive biomass differs from the native biomass in chemical quality e.g. lignin and nutrient content, $\mathrm{C} / \mathrm{N}$ and lignin $\mathrm{N}$ ratios and/or secondary metabolites [107] [108] [109]. Sites with invasive plants can affect soil processes through root exudases and enhanced rates of litter decomposition, a process mediated by the soil microbial community, thereby accelerating nutrient cycling and the subsequent release of available N and P into soils [110] [111] [112]. The growth rate (RGR) of Rumex confertus, another invasive species, was also found to increase with increasing nutrient (N, P, K) supply [113].

Changes in soil properties brought about by plant invasions can be problematic as they may lead to feedbacks that stabilize or accelerate further invasion [85]. There still continues to be an increased availability of $\mathrm{N}$ from various urban contaminant sources and atmospheric nitrogen depositions which is a major environmental change factor [19]. Moreover, $\mathrm{N}$ has been suggested to be an important limiting factor to fast growing invasive species including week invaders [114] which could possibly be the reason for the presence of multiple invasive species that are being increasingly reported from urban areas [115] [116].

The processes influencing urban plant species patterns are highly complex ranging from soil compaction, pollution, habitat fragmentation, high disturbance regimes along with the changing climatic factors. Since biodiversity in urban and suburban areas can decline either due to habitat transformation or landscape fragmentation, vegetation can be an important indicator of urbanization pressure on biodiversity in cities. Thus, surveys aimed at investigating floristic diversity in cities of tropical areas could be useful for understanding the present ecological changes in order to undertake effective management procedures to make cities ecologically and socially sustainable.

\section{Acknowledgements}

The authors would like to thank Indian Statistical Institute (ISI), Kolkata, India for funding of this research. We are grateful to Prof. Anup Dewanji, Applied Statistics Unit, Indian Statistical Institute, for his valuable statistical guidance. Ms. Arpita Ganguly, Mr. Sandip Chatterjee, Mr. Susant Mahankur and Jahira Begum, AERU, ISI are acknowledged for technical assistance.

\section{Conflicts of Interest}

The authors declare no conflicts of interest regarding the publication of this paper.

\section{References}

[1] Lepczyk, C.A., Aronson, M.F.J., Evans, K.L., Goddard, M.A., Lerman, S.B. and Maclvor, J.S. (2017) Biodiversity in the City: Fundamental Questions for Understanding the Ecology of Urban Green Spaces for Biodiversity Conservation. Bios cience, 67, 799-807. https://doi.org/10.1093/biosci/bix079 
[2] Azam, M. and Khan, A.Q. (2016) Urbanization and Environmental Degradation: Evidence from four SAARC Countries-Bangladesh, India, Pakistan, and Sri Lanka. Environmental Progress and Sustainable Energy, 35, 823-832. https://doi.org/10.1002/ep.12282

[3] Maiti, S. and Agarwal, P.K. (2005) Environmental Degradation in the Context of Growing Urbanization: A Focus on the Metropolitan Cities of India. Journal of Human Ecology, 17, 277-287. https://doi.org/10.1080/09709274.2005.11905793

[4] Patra, S., Sahoo, S., Mishra, P. and Mahapatra, S.C. (2018) Impacts of Urbanization on Land Use/Cover Changes and Its Probable Implications on Local Climate and Ground Water Level. Journal of Urban Management, 7, 70-84.

https://doi.org/10.1016/j.jum.2018.04.006

[5] Gregory, A.S., Ritz, K., McGrath, S.P., Quinton, J.N., Goulding, K.W.T., Jones, R.J.A., Harris, J.A., Bol, R., Wallace, P., Pilgrim, E.S. and Whitmore, A.P. (2015) A Review of the Impacts of Degradation Threats on Soil Properties in the UK. Soil Use and Management, 31, 1-15. https://doi.org/10.1111/sum.12212

[6] Pouyat, R., Groffman, P., Yesilonis, I. and Hernandez, L. (2002) Soil Carbon Pools and Fluxes in Urban Ecosystems. Environmental Pollution, 116, S107-S118. https://doi.org/10.1016/S0269-7491(01)00263-9

[7] Pouyat, R.V., Szlavecz, K., Yesilonis, I.D., Groffman, P.M. and Schwarz, K. (2010) Chemical, Physical, and Biological Characteristics of Urban Soils in Urban Ecosystem Ecology. In: Aitkenhead-Peterson, J. and Volder, A., Ed., Urban Ecosystem Ecology, Agronomy Monograph 55, American Society of Agronomy, Crop Science Society of America, Soil Science Society of America, Madison, 119-152.

[8] Susca, T., Gaffin, S.R. and Dell'Osso, G.R. (2011) Positive Effects of Vegetation: Urban Heat Island and Green Roofs. Environmental Pollution, 159, 2119-2126. https://doi.org/10.1016/j.envpol.2011.03.007

[9] Wu, J. (2014) Urban Ecology and Sustainability: The State-of-the-Science and Future Directions. Landscape and Urban Planning, 125, 209-221. https://doi.org/10.1016/j.landurbplan.2014.01.018

[10] Pouyat, R., Yesilonis, I., Russell-Anelli, J. and Neerchal, N. (2007) Soil Chemical and Physical Properties That Differentiate Urban Land-Use and Cover Types. Soil Science Society of America Journal, 71, 1010-1019. https://doi.org/10.2136/sssaj2006.0164

[11] McDonald, R.I., Marcotullio, P.J. and Güneralp, B. (2013) Urbanization and Global Trends in Biodiversity and Ecosystem Services. In: Elmqvist, T., et al., Eds., Urbanization, Biodiversity and Ecosystem Services. Challenges and Opportunities, Springer, Dordrecht. https://doi.org/10.1007/978-94-007-7088-1_3

[12] Li, J.D., Deng, J.S., Gu, Q., Wang, K., Ye, F.J., Xu, Z.H. and Jin, S. (2015) The Accelerated Urbanization Process: A Threat to Soil Resources in Eastern China. Sustainability, 7, 7137-7155. https://doi.org/10.3390/su7067137

[13] Hung, T., Uchihama, D., Ochi, S. and Yasuoka, Y. (2006) Assessment with Satellite Data of the Urban Heat Island Effects in Asian Mega Cities. International Journal of Applied Earth Observation and Geoinformation, 8, 34-48. https://doi.org/10.1016/j.jag.2005.05.003

[14] Estoque, R.C., Murayama, Y. and Myint, S.W. (2017) Effects of Landscape Composition and Pattern on Land Surface Temperature: An Urban Heat Island Study in the Megacities of Southeast Asia. Science of the Total Environment, 577, 349-359. https://doi.org/10.1016/j.scitotenv.2016.10.195

[15] Grimm, N.B., Foster, D., Groffman, P., Grove, J.M., Hopkinson, C.S., Nadelhoffer, 
K.J., Pataki, D.E. and Peters, D.P.C. (2008) The Changing Landscape: Ecosystem Responses to Urbanization and Pollution across Climatic and Societal Gradients. Frontiers in Ecology and the Environment, 6, 264-272. https://doi.org/10.1890/070147

[16] Wright, L.P., Zhang, L., Cheng, I., Aherne, J. and Wentworth, G.R. (2018) Impacts and Effects Indicators of Atmospheric Deposition of Major Pollutants to Various Ecosystems-A Review. Aerosol and Air Quality Research, 18, 1953-1992. https://doi.org/10.4209/aaqr.2018.03.0107

[17] Gaertner, M., Wilson, J.R.U., Cadotte, M.W., MacIvor, J.S., Zenni, R.D. and Richardson, D.M. (2017) Non-Native Species in Urban Environments: Patterns, Processes, Impacts and Challenges. Biological Invasions, 19, 3461-3469. https://doi.org/10.1007/s10530-017-1598-7

[18] Phoenix, G.K., Hicks, W.K., Cinderby, S., Kuylenstierna, C.I., Stock, W.D., Dentener, F.J., Giller, K.E., Austin, A.T., Lefroy, D.B., Gimeno, B.S., Ashmore, M.R. and Ineson, P. (2006) Atmospheric Nitrogen Deposition in World Biodiversity Hotspots: The Need for a Greater Global Perspective in Assessing N Deposition Impacts. Global Change Biology, 12, 470-476. https://doi.org/10.1111/j.1365-2486.2006.01104.x

[19] Galloway, J.N., Townsend, A.R., Erisman, J.W., Bekunda, M., Cai, Z., Freney, J.R., Martinelli, L.A., Seitzinger, S.P. and Sutton, M.A. (2008) Transformation of the Nitrogen Cycle: Recent Trends, Questions, and Potential Solutions. Science, 320, 889-892. https://doi.org/10.1126/science.1136674

[20] Payne, R.J., Dise, N.B., Field, C.D., Dore, A.J., Carpon, S.J. and Stevens, C.J. (2017) Nitrogen Deposition and Plant Biodiversity: Past, Present, and Future. Frontiers in Ecology and the Environment, 15, 431-436. https://doi.org/10.1002/fee.1528

[21] Díaz-Álvarez, E.A., Lindig-Cisneros, R. and de la Barrera, E. (2018) Biomonitors of Atmospheric Nitrogen Deposition: Potential Uses and Limitations. Conservation Physiology, 6, coy011. https://doi.org/10.1093/conphys/coy011

[22] Walther, G.R., Roques, A., Hulme, P.E., Sykes, M.T., Pysek, P., Kuhn, I., Zobel, M., Bacher, S., Botta-Dukat, Z., Bugmann, H., Czucz, B., Dauber, J., Hickler, T., Jarosik, V., Kenis, M., Klotzm S., Minchin, D., Moora, M., Nentwig, W., Ott, J., Panov, V.E., Reineking, B., Robinet, C., Semenchenko, V., Solarz, W., Thuiller, W., Vila, M., Vohland, K. and Settele, J. (2009) Alien Species in a Warmer World: Risks and Opportunities. Trends in Ecology \& Evolution, 24, 686-693.

https://doi.org/10.1016/j.tree.2009.06.008

[23] Inderjit, Pergl, J., van Kleunen, M., Hejda, M., Babu, C.R., Majumdar, S., Singh, P., Singh, S.P., Salamma, S., Rao, B.R.P. and Pyšek, P. (2017) Naturalized Alien Flora of the Indian States: Biogeographic Patterns, Taxonomic Structure and Drivers of Species Richness. Biological Invasions, 20, 1625-1638. https://doi.org/10.1007/s10530-017-1622-y

[24] Panda, R.M., Behera. M.D. and Roy, P.S. (2018) Assessing Distributions of Two Invasive Species of Contrasting Habits in Future Climate. Journal of Environmental Management, 213, 478-488. https://doi.org/10.1016/j.jenvman.2017.12.053

[25] Tripathi, P., Behera, M.D. and Roy, P.S. (2019) Plant Invasion Correlation with Climate Anomaly: An Indian Retrospect. Biodiversity and Conservation, 28, 2049-2062. https://doi.org/10.1007/s10531-019-01711-0

[26] Hawkins, B.A., Field, R., Cornell, H.V., Currie, D.J., Guegan, J.F., Kaufman, D.M., Kerr, J.T., Mittelbach, G.G., Oberdorff, T., O’Brien, E.M., Porter, E.E. and Turner, J.R.G. (2003) Energy, Water and Broad Scale Geographic Patterns of Species Rich- 
ness. Ecology, 84, 3105-3117. https://doi.org/10.1890/03-8006

[27] Velazco, S.J.E., Galvão, F., Villalobos, F. and Júnior, P.D.M. (2017) Using Worldwide Edaphic Data to Model Plant Species Niches: An Assessment at a Continental Extent. PLoS ONE, 12, e0186025. https://doi.org/10.1371/journal.pone.0186025

[28] Bansal, S., James, J.J. and Sheley, R.L. (2014) The Effects of Precipitation and Soil Type on Three Invasive Annual Grasses in the Western United States. Journal of Arid Environments, 104, 38-42. https://doi.org/10.1016/j.jaridenv.2014.01.010

[29] Gervazio, W., Yamashita, O. M., Felito, R.A. and Eisenlohr, P.V. (2019) Soil Quality and Its Relationship with Weeds in Urban Homegardens of Alta Floresta, Southern Amazonia. Agroforestry Systems, 93, 1223-1234. https://doi.org/10.1007/s10457-018-0230-x

[30] Tabassum, S. and Leishman, M.R. (2016) Trait Values and Not Invasive Status Determine Competitive Outcomes between Native and Invasive Species under Varying Soil Nutrient Availability. Austral Ecology, 41, 875-885. https://doi.org/10.1111/aec.12379

[31] Fuller, R.A., Irvine, K.N., Devine-Wright, P., Warren, P.H. and Gaston, K.J. (2007) Psychological Benefits of Greenspace Increase with Biodiversity. Biology Letters, 3, 390-394. https://doi.org/10.1098/rsbl.2007.0149

[32] Irvine, K.N., Fuller, R.A., Devine-Wright, P., Tratalos, J., Payne, S.R., Warren, P.H., Lomas, K.J. and Gaston, K.J. (2010) Ecological and Psychological Value of Urban Green Space. In: Jenks, M. and Jones, C., Eds., Dimensions of the Sustainable City, Springer, Dordrecht, Future City Vol. 2, 215-237. https://doi.org/10.1007/978-1-4020-8647-2_10

[33] Southon, G.E., Jorgensen, A., Dunnett, N., Hoyle, H. and Evans, K.L. (2018) Perceived Species-Richness in Urban Green Spaces: Cues, Accuracy and Well-Being Impacts. Landscape and Urban Planning, 172, 1-10. https://doi.org/10.1016/j.landurbplan.2017.12.002

[34] Kühn, I., Wolf, J. and Schneider, A. (2017) Is There an Urban Effect in Alien Plant Invasions? Biological Invasions, 19, 3505-3513. https://doi.org/10.1007/s10530-017-1591-1

[35] KMC (2015) Basic Statistics of Kolkata. https://www.kmcgov.in/KMCPortal/jsp/KolkataStatistics.jsp

[36] Sahana, M., Hong, H. and Sajjad, H. (2018) Analyzing Urban Spatial Patterns and Trend of Urban Growth Using Urban Sprawl Matrix: A Study on Kolkata Urban Agglomeration, India. Science of the Total Environment, 628-629, 1557-1566. https://doi.org/10.1016/j.scitotenv.2018.02.170

[37] Dasgupta, S., Gosain, A.K., Rao, S., Roy, S. and Sarraf, M.A. (2013) A Megacity in a Changing Climate: The Case of Kolkata. Climate Change, 116, 747-766. https://doi.org/10.1007/s10584-012-0516-3

[38] AOAC (2012) Official Methods of Analysis. 19th Edition, Association of Official Analytical Chemist, Washington DC.

[39] Olsen, S.R., Cole, C.V., Watanabe, F.S. and Dean, L.A. (1954) Estimation of Available Phosphorus in Soils by Extraction with Sodium Bicarbonate. Circular US Department of Agriculture, Vol. 939, 1-19.

[40] Jackson, M.L. (1958) Soil Chemical Analysis. Prentice-Hall Inc., Englewood Cliffs.

[41] Walkley, A. and Black, I.A. (1934) An Examination of Degtjareff Method for Determining Soil Organic Matter and a Proposed Modification of the Chromic Acid Titration Method. Soil Science, 37, 29-37. 
https://doi.org/10.1097/00010694-193401000-00003

[42] Kühn, I., Brandl, R. and Klotz, S. (2004) The Flora of German Cities Is Naturally Species Rich. Evolutionary Ecology Research, 6, 749-764.

[43] Richardson, D.M., Pyšek, P., Rejmanek, M., Barbour, M.G., Panetta, F.D. and West, C.J. (2000) Naturalization and Invasion of Alien Plants: Concepts and Definitions. Diversity and Distributions, 6, 93-107. https://doi.org/10.1046/j.1472-4642.2000.00083.x

[44] Stajerová, K., Šmilauer, P., Brůna, J. and Pyšek, P. (2017) Distribution of Invasive Plants in Urban Environment Is Strongly Spatially Structured. Landscape Ecology, 32, 681-692. https://doi.org/10.1007/s10980-016-0480-9

[45] Lilleskov, E., Callaham, M.A., Pouyat, R., Smith, J.E., Castellano, M., Gonzalez, G., Lodge, D.J., Arango, R. and Green, F. (2010) Invasive Soil Organisms and Their Effects on Belowground Processes. In: Dix, M.E. and Britton, K., Eds., A Dynamic Invasive Species Research Vision: Opportunities and Priorities 2009-29, USDA Forest Service, Research and Development GTR WO-79/83, Washington DC, 67-83.

[46] Ehrenfeld, J., Kourtev, P. and Huang, W. (2001) Changes in Soil Functions Following Invasions of Exotic Understory Plants in Deciduous Forests. Ecological Applications, 11, 1287-1300. https://doi.org/10.1890/1051-0761(2001)011[1287:CISFFI]2.0.CO;2

[47] Perrings, C., Mooney, H. and Williamson, M. (2010) Bioinvasions and Globalization-Ecology, Economics, Management and Policy. Oxford University Press, New York. https://doi.org/10.1093/acprof:oso/9780199560158.001.0001

[48] Osunkoya, O.O. and Perrett, C. (2011) Lantana camara L. (Verbenaceae) Invasion Effects on Soil Physicochemical Properties. Biology and Fertility of Soils, 47, 349-355. https://doi.org/10.1007/s00374-010-0513-5

[49] Bullock, P. and Gregory, P.J. (1991) Soils in Urban Environment. Blackwell Scientific Publications, London, 1-192. https://doi.org/10.1002/9781444310603

[50] Mao, Q., Huang, G., Buyantuev, A., Wu, J., Luo, S. and Ma, K. (2014) Spatial Heterogeneity of Urban Soils: The Case of the Beijing Metropolitan Region, China. Ecological Processes, 3, 23. https://doi.org/10.1186/s13717-014-0023-8

[51] Lehmann, A. and Stahr, K. (2007) Nature and Significance of Anthropogenic Urban Soils. Journal of Soils and Sediments, 7, 247-260. https://doi.org/10.1065/jss2007.06.235

[52] Lorenz, K. and Lal, R. (2009) Biogeochemical C and N Cycles in Urban Soils. Environment International, 35, 1-8. https://doi.org/10.1016/j.envint.2008.05.006

[53] Scalenghe, R. and Marsan, F.A. (2009) The Anthropogenic Sealing of Soils in Urban Areas. Landscape and Urban Planning, 90, 1-10. https://doi.org/10.1016/j.landurbplan.2008.10.011

[54] Kumar, K. and Hundal, L.S. (2016) Soil in the City: Sustainably Improving Urban Soils. Journal of Environmental Quality, 45, 2-8. https://doi.org/10.2134/jeq2015.11.0589

[55] Hu, B., Jia, X., Hu, J., Xu, D., Xia, F. and Li, Y. (2017) Assessment of Heavy Metal Pollution and Health Risks in the Soil-Plant-Human System in the Yangtze River Delta, China. International Journal of Environmental Research and Public Health, 14, 1042. https://doi.org/10.3390/ijerph14091042

[56] Pan, L., Wang, Y., Ma, J., Hu, Y., Su, B., Fang, G., Wang, L. and Xiang, B. (2018) A Review of Heavy Metal Pollution Levels and Health Risk Assessment of Urban Soils. Environmental Science and Pollution Research, 25, 1055-1069. 
https://doi.org/10.1007/s11356-017-0513-1

[57] Adimalla, N. (2019) Heavy Metals Pollution Assessment and Its Associated Human Health Risk Evaluation of Urban Soils from Indian Cities: A Review. Environmental Geochemistry and Health. https://doi.org/10.1007/s10653-019-00324-4

[58] Lorenz, K. and Kandeler, E. (2005) Biochemical Characterization of Urban Soil Profiles from Stuttgart, Germany. Soil Biology and Biochemistry, 37, 1373-1385. https://doi.org/10.1016/j.soilbio.2004.12.009

[59] Baveye, P.C., Baveye, J. and Gowdy, J. (2016) Soil "Ecosystem" Services and Natural Capital: Critical Appraisal of Research on Uncertain Ground. Frontiers in Environmental Science, 4, 609. https://doi.org/10.3389/fenvs.2016.00041

[60] Liu, R., Wang, M. and Chen, W. (2018) The Influence of Urbanization on Organic Carbon Sequestration and Cycling in Soils of Beijing. Landscape and Urban Planning, 169, 241-249. https://doi.org/10.1016/j.landurbplan.2017.09.002

[61] Li, Z.G., Zhang, G.S., Liu, Y., Wan, K.Y., Zhang, R.H. and Chen, F. (2013) Soil Nutrient Assessment for Urban Ecosystems in Hubei, China. PLoS ONE, 8, e75856. https://doi.org/10.1371/journal.pone.0075856

[62] Asabere, S.B., Zeppenfeld, T., Nketia, K.A. and Sauer, D. (2018) Urbanization Leads to Increases in $\mathrm{pH}$, Carbonate, and Soil Organic Matter Stocks of Arable Soils of Kumasi, Ghana (West Africa). Frontiers in Environmental Science, 6, 119. https://doi.org/10.3389/fenvs.2018.00119

[63] Scharenbroch, B.C., Lloyd, J.E. and Johnson-Maynard, J.L. (2005) Distinguishing Urban Soils with Physical, Chemical, and Biological Properties. Pedobiologia, 49, 283-296. https://doi.org/10.1016/j.pedobi.2004.12.002

[64] Zhang, K., Xu, X.N. and Wang, Q. (2010) Characteristics of N Mineralization in Urban Soils of Hefei, East China. Pedosphere, 20, 236-244. https://doi.org/10.1016/S1002-0160(10)60011-2

[65] Weidenhamer, J.D. and Callaway, R.M. (2010) Direct and Indirect Effects of Invasive Plants on Soil Chemistry and Ecosystem Function. Journal of Chemical Ecolo$g y$, 36, 59-69. https://doi.org/10.1007/s10886-009-9735-0

[66] McGrath, S.P., Chaudri, A.M. and Giller, K.E. (1995) Long-Term Effects of Metals in Sewage Sludge on Soils, Microorganisms and Plants. Journal of Industrial Microbiology \& Biotechnology, 14, 94-104. https://doi.org/10.1007/BF01569890

[67] Sun, Y., Ma, J. and Li, C. (2010) Content and Densities of Soil Organic Carbon in Urban Soil in Different Function Districts of Kaifeng. Journal of Geographical Sciences, 20, 148-156. https://doi.org/10.1007/s11442-010-0148-3

[68] Gupta, K., Arnold, F. and Lhungdim, H. (2009) Health and Living Conditions in Eight Indian Cities. National Family Health Survey (NFHS-3), India, 2005-06. International Institute for Population Sciences, Mumbai, ICF Macro, Calverton, 44. https://dhsprogram.com/pubs/pdf/od58/od58.pdf

[69] Kaye, J., Majumdar, A., Gries, C., Buyantuyev, A., Grimm, N., Hope, D., Jenerette, G., Zhu, W. and Baker, L. (2008) Hierarchical Bayesian Scaling of Soil Properties across Urban, Agricultural, and Desert Ecosystems. Ecological Applications, 18, 132-145. https://doi.org/10.1890/06-1952.1

[70] Decina, S.M., Templer, P.H., Hutyra, L.R., Gately, C.K. and Rao, P. (2017) Variability, Drivers, and Effects of Atmospheric Nitrogen Inputs across an Urban Area: Emerging Patterns among Human Activities, the Atmosphere, and Soils. Science of the Total Environment, 609, 1524-1534.

https://doi.org/10.1016/j.scitotenv.2017.07.166 
[71] Gruber, N. and Galloway, J.N. (2008) An Earth-System Perspective of the Global Nitrogen Cycle. Nature, 451, 293-296. https://doi.org/10.1038/nature06592

[72] Huang, L., Wang, H., Li, Y. and Lu, S. (2013) Spatial Distribution and Risk Assessment of Phosphorus Loss Potential in Urban-Suburban Soil of Lishui, China. Catena, 100, 42-49. https://doi.org/10.1016/j.catena.2012.08.011

[73] Smil, V. (2000) Phosphorus in the Environment: Natural Flows and Human Interferences. Annual Review of Energy and the Environment, 25, 53-88. https://doi.org/10.1146/annurev.energy.25.1.53

[74] Nyenje, P.M., Foppen, J.W., Uhlenbrook, S., Kulabako, R. and Muwanga, A. (2010) Eutrophication and Nutrient Release in Urban Areas of Sub-Saharan Africa-A Review. Science of the Total Environment, 408, 447-455. https://doi.org/10.1016/j.scitotenv.2009.10.020

[75] McCrea, A.R., Trueman, I.C., Fullen, M.A., Atkinson, M.D. and Besenyei, L. (2001) Relationships between Soil Characteristics and Species Richness in Two Botanically Heterogeneous Created Meadows in the Urban English West Midlands. Biological Conservation, 97, 171-180. https://doi.org/10.1016/S0006-3207(00)00109-9

[76] Amundson, R. (2001) The Carbon Budget in Soils. Annual Review of Earth and Planetary Sciences, 29, 535-562. https://doi.org/10.1146/annurev.earth.29.1.535

[77] Cardoso, E.J.B.N., Vasconcellos, R.L.F., Bini, D., Miyauchi, M.Y.H., dos Santos, C.A., Alves, P.R.L., de Paula, A.M., Nakatani, A.S., Pereira, J.M. and Nogueira, M.A. (2013) Soil Health: Looking for Suitable Indicators. What Should Be Considered to Assess the Effects of Use and Management on Soil Health? Scientia Agricola, 70, 274-289. https://doi.org/10.1590/S0103-90162013000400009

[78] Tratalos, J., Fuller, R.A., Warren, P.H., Davies, R.G. and Gaston, K.J. (2007) Urban Form, Biodiversity Potential and Ecosystem Services. Landscape and Urban Planning, 83, 308-317. https://doi.org/10.1016/j.landurbplan.2007.05.003

[79] Vasenev, V.I., Prokof eva, T.V. and Makarov, O.A. (2013) The Development of Approaches to Assess the Soil Organic Carbon Pools in Megapolises and Small Settlements. Eurasian Soil Science, 46, 685-696. https://doi.org/10.1134/S1064229313060100

[80] Pickett, S.T.A., Cadenasso, M.L., Grove, J.M., Groffmann, P.N., Band, L.E., Boone, C.G., Burch, W.R., Grimmond, S.B., Hom, J., Jenkins, J.C., Law, N.L., Nilon, C.H., Pouyat, R.V., Szlavecz, K., Warren, P.S. and Wilson, M.A. (2008) Beyond Urban Legends: An Emerging Framework of Urban Ecology, as Illustrated by the Baltimore Ecosystem Study. BioScience, 58, 139-150. https://doi.org/10.1641/B580208

[81] Ehrenfeld, J.G. (2003) Effects of Exotic Plant Invasions on Soil Nutrient Cycling Processes. Ecosystems, 6, 503-523. https://doi.org/10.1007/s10021-002-0151-3

[82] Chen, X., Liu, Y., Liu, H., Wang, H., Yang, D. and Huangfu, C. (2015) Impacts of Four Invasive Asteraceae on Soil Physico-Chemical Properties and AM Fungi Community. American Journal of Plant Sciences, 6, 2734-2743. https://doi.org/10.4236/ajps.2015.617274

[83] Kourtev, P., Ehrenfeld, J. and Häggblom, M. (2003) Experimental Analysis of the Effect of Exotic and Native Plant Species on the Structure and Function of Soil Microbial Communities. Soil Biology and Biochemistry, 35, 895-905. https://doi.org/10.1016/S0038-0717(03)00120-2

[84] Batten, K.M., Scow, K.M., Davies, K.F. and Harrison, S.P. (2006) Two Invasive Plants Alter Soil Microbial Community Composition in Serpentine Grasslands. Biological Invasions, 8, 217-230. https://doi.org/10.1007/s10530-004-3856-8 
[85] Stefanowicz, A.M., Majewska, M.L., Stanek, M., Nobis, M. and Zubek, S. (2018) Differential Influence of Four Invasive Plant Species on Soil Physicochemical Properties in a Pot Experiment. Journal of Soils and Sediments, 18, 1409-1423. https://doi.org/10.1007/s11368-017-1873-3

[86] Elser, J.J., Bracken, M.E.S., Cleland, E.E., Gruner, D.S., Harpole, W.S., Hillebrand, H., Ngai, J.T., Seabloom, E.W., Shurin, J.B. and Smith, J.E. (2007) Global Analysis of Nitrogen and Phosphorus Limitation of Primary Producers in Freshwater, Marine and Terrestrial Ecosystems. Ecology Letters, 10, 1135-1142.

https://doi.org/10.1111/j.1461-0248.2007.01113.x

[87] Vitousek, P.M., Porder, S., Houlton, B.Z. and Chadwick, O.A. (2010) Terrestrial Phosphorus Limitation: Mechanisms, Implications, and Nitrogen-Phosphorus Interactions. Ecological Applications, 20, 5-15. https://doi.org/10.1890/08-0127.1

[88] Agren, G.I., Wetterstedt, J.A.M. and Billberger, M.F.K. (2012) Nutrient Limitation on Terrestrial Plant Growth-Modeling the Interaction between Nitrogen and Phosphorus. New Phytologist, 194, 953-960. https://doi.org/10.1111/j.1469-8137.2012.04116.x

[89] Maskell, L.C., Smart, S.M., Bullock, J.M., Thompson, K. and Stevens, C.J. (2010) Nitrogen Deposition Causes Widespread Loss of Species Richness in British Habitats. Global Change Biology, 16, 671-679. https://doi.org/10.1111/j.1365-2486.2009.02022.x

[90] Daufresne, T. and Hedin, L.O. (2005) Plant Coexistence Depends on Ecosystem Nutrient Cycles: Extension of the Resource-Ratio Theory. Proceedings of the National Academy of Sciences of the United States of America, 102, 9212-9217. https://doi.org/10.1073/pnas.0406427102

[91] Brooks, M.L. (2003) Effects of Increased Soil Nitrogen on the Dominance of Alien Annual Plants in the Mojave Desert. Journal of Applied Ecology, 40, 344-353. https://doi.org/10.1046/j.1365-2664.2003.00789.x

[92] Littschwager, J., Lauerer, M., Blagodatskaya, E. and Kuzyakov, Y. (2010) Nitrogen Uptake and Utilisation as a Competition Factor between Invasive Duchesnea indica and Native Fragaria vesca. Plant Soil, 331, 105-114. https://doi.org/10.1007/s11104-009-0236-2

[93] Li, X., Rennenberg, H. and Simon, J. (2015) Competition for Nitrogen between Fagus sylvatica and Acer pseudoplatanus Seedlings Depends on Soil Nitrogen Availability. Frontiers in Plant Science, 6, 302. https://doi.org/10.3389/fpls.2015.00302

[94] Seabloom, E.W., Borer, E.T., Buckley, Y.M., Cleland, E.E., Davies, K.F., Firn, J., Harpole, W.S., Hautier, Y., Lind, E.M., MacDougall, A.S., Orrock, J.L., Prober, S.M., Adler, P.B., Anderson, T.M., Bakker, J.D., Biederman, L.A., Blumenthal, D.M., Brown, C.S., Brudvig, L.A., Cadotte, M., Chu, C., Cottingham, K.L., Crawley, M.J., Damschen, E.I., D’Antonio, C.M., DeCrappeo, N.M., Du, G., Fay, P.A., Frater, P., Gruner, D.S., Hagenah, N., Hector, A., Hillebrand, H., Hofmockel, K.S., Humphries, H.C., Jin, V.L., Kay, A., Kirkman, K.P., Klein, J.A., Knops, J.M.H., La Pierre, K.J., Ladwig, L., Lambrinos, J.G., Li, Q., Li, W., Marushia, R., McCulley, R.L., Melbourne, B.A., Mitchell, C.E., Moore, J.L., Morgan, J., Mortensen, B., O’Halloran, L.R., Pyke, D.A., Risch, A.C., Sankaran, M., Schuetz, M., Simonsen, A., Smith, M.D., Stevens, C.J., Sullivan, L., Wolkovich, E., Wragg, P.D., Wright, J. and Yang, L. (2015) Plant Species' Origin Predicts Dominance and Response to Nutrient Enrichment and Herbivores in Global Grasslands. Nature Communications, 6, 1-8. https://doi.org/10.1038/ncomms8710

[95] Flores-Moreno, H., Reich, P.B., Lind, E.M., Sullivan, L.L., Seabloom, E.W., Yahdjian, L., MacDougall, A.S., Reichmann, L.G., Alberti, J., Báez, S., Bakker, J.D., Ca- 
dotte, M.W., Caldeira, M.C., Chaneton, E.J., D’Antonio, C.M., Fay, P.A., Firn, J., Hagenah, N., Harpole, W.S., Iribarne, O., Kirkman, K.P., Knops, J.M.H., La Pierre, K.J., Laungani, R., Leakey, A.D.B., McCulley, R.L., Moore, J.L., Pascual, J. and Borer, E.T. (2016) Climate Modifies Response of Non-Native and Native Species Richness to Nutrient Enrichment. Philosophical Transactions of the Royal Society B: Biological Sciences, 371, Article ID: 20150273. https://doi.org/10.1098/rstb.2015.0273

[96] Hawkes, C.V., Wren, I.F., Herman, D.J. and Firestone, M.K. (2005) Plant Invasion Alters Nitrogen Cycling by Modifying the Soil Nitrifying Community. Ecology Letters, 8, 976-985. https://doi.org/10.1111/j.1461-0248.2005.00802.x

[97] Laungani, R. and Knops, J.M.H. (2009) Species-Driven Changes in Nitrogen Cycling Can Provide a Mechanism for Plant Invasions. Proceedings of the National Academy of Sciences of the United States of America, 106, 12400-12405. https://doi.org/10.1073/pnas.0900921106

[98] Liao, C.Z., Peng, R.H., Luo, Y.Q., Zhou, X.H., Wu, X.W., Fang, C.M., Chen, J.K. and Li, B. (2008) Altered Ecosystem Carbon and Nitrogen Cycles by Plant Invasion: A Meta Analysis. New Phytologist, 177, 706-714. https://doi.org/10.1111/j.1469-8137.2007.02290.x

[99] Elgersma, K.J., Ehrenfeld, J.G., Yu, S. and Vor, T. (2011) Legacy Effects Overwhelm the Short-Term Effects of Exotic Plant Invasion and Restoration on Soil Microbial Community Structure, Enzyme Activities, and Nitrogen Cycling. Oecologia, 167, 733-745. https://doi.org/10.1007/s00442-011-2022-0

[100] Vilà, M., Espinar, J.L., Hejda, M., Hulme, P.E., Jarošík, V., Maron, J.L., Perg, J., Schaffner, U., Sun, Y. and Pyšek, P. (2011) Ecological Impacts of Invasive Alien Plants: A Meta-Analysis of Their Effects on Species, Communities and Ecosystems. Ecology Letters, 14, 702-708. https://doi.org/10.1111/j.1461-0248.2011.01628.x

[101] Gundale, M.J., Sutherland, S. and DeLuca, T.H. (2008) Fire, Native Species, \& Soil Resource Interactions Influence the Spatio-Temporal Invasion Pattern of Bromus tetorum. Ecography, 31, 201-210. https://doi.org/10.1111/j.0906-7590.2008.5303.x

[102] Li, W.H., Zhang, C.B., Lin, J.Y. and Yang, C.J. (2008) Characteristics of Nitrogen Metabolism and Soil Nitrogen of Invasive Plants. Journal of Tropical and Subtropical Botany, 16, 321-327.

[103] Bashkin, M., Stohlgren, T.J., Otsuki, Y., Lee, M., Evangelista, P. and Belnap, J. (2003) Soil Characteristics and Plant Exotic Species Invasions in the Grand Staircase-Escalante National Monument, Utah, USA. Applied Soil Ecology, 22, 67-77. https://doi.org/10.1016/S0929-1393(02)00108-7

[104] Parepa, M., Fischer, M. and Bossdorf, O. (2013) Environmental Variability Promotes Plant Invasion. Nature Communications, 4, 1604. https://doi.org/10.1038/ncomms2632

[105] Rickey, M.A. and Anderson, R.C. (2004) Effects of Nitrogen Addition on the Invasive Grass Phragmites australis and a Native Competitor Spartina pectinata. Journal of Applied Ecology, 41, 888-896. https://doi.org/10.1111/j.0021-8901.2004.00948.x

[106] Bobbink, R., Hicks, K., Galloway, J., Spranger, T., Alkemade, R., Ashmore, M., Bustamante, M., Cinderby, S., Davidson, E., Dentener, F., Emmett, B., Erisman, J.W., Fenn, M., Gilliam, F., Nordin, A., Pardo, L. and De Vries, W. (2010) Global Assessment of Nitrogen Deposition Effects on Terrestrial Plant Diversity: A Synthesis. Ecological Applications, 20, 30-59. https://doi.org/10.1890/08-1140.1

[107] Dassonville, N., Vanderhoeven, S., Gruber, W. and Meerts, P. (2007) Invasion by Fallopia japonica Increases Topsoil Mineral Nutrient Concentrations. Ecoscience, 14, 230-240. https://doi.org/10.2980/1195-6860(2007)14[230:IBFJIT]2.0.CO;2 
[108] Tharayil, N., Alpert, P., Bhowmik, P. and Gerard, P. (2013) Phenolic Inputs by Invasive Species Could Impart Seasonal Variations in Nitrogen Pools in the Introduced Soils: A Case Study with Polygonum cuspidatum. Soil Biology and Biochemistry, 57, 858-867. https://doi.org/10.1016/j.soilbio.2012.09.016

[109] Liu, Y.Y., Sun, Y., Müller-Schärer, H., Yan, R., Zhou, Z.X., Wang, Y.J. and Yu, F.H. (2019) Do Invasive Alien Plants Differ from Non-Invasives in Dominance and Nitrogen Uptake in Response to Variation of Abiotic and Biotic Environments under Global Anthropogenic Change? Science of the Total Environment, 772, 634-642. https://doi.org/10.1016/j.scitotenv.2019.04.024

[110] Haichar, F.Z., Santaella, C., Heulin, T. and Achouak, W. (2014) Root Exudates Mediated Interactions Belowground. Soil Biology and Biochemistry, 77, 69-80. https://doi.org/10.1016/j.soilbio.2014.06.017

[111] Ruckli, R., Hesse, K., Glauser, G., Rusterholz, H.P. and Baur, B. (2014) Inhibitory Potential of Naphthoquinones Leached from Leaves and Exuded from Roots of the Invasive Plant Impatiens glandulifera. Journal of Chemical Ecology, 40, 371-378. https://doi.org/10.1007/s10886-014-0421-5

[112] Zhou, Y. and Staver, A.C. (2019) Enhanced Activity of Soil. Nutrient-Releasing Enzymes after Plant Invasion: A Meta-Analysis. Ecology, 100, e02830. https://doi.org/10.1002/ecy.2830

[113] Kołodziejek, J. (2019) Growth and Competitive Interaction between Seedlings of an Invasive Rumex confertus and of Co-Occurring Two Native Rumex Species in Relation to Nutrient Availability. Scientific Reports, 9, 3298. https://doi.org/10.1038/s41598-019-39947-z

[114] Mozdzer, T.J. and Megonigal, J.P. (2012) Jack-and-Master Trait Responses to Elevated $\mathrm{CO}_{2}$ and $\mathrm{N}$ : A Comparison of Native and Introduced Phragmites australis. PLoS ONE, 7, e4279410. https://doi.org/10.1371/journal.pone.0042794

[115] Botham, M.S., Rothery, P., Hulme, P.E., Hill, M.O., Preston, C.D. and Roy, D.B. (2009) Do Urban Areas Act as Foci for the Spread of Alien Plant Species? An Assessment of Temporal Trends in the UK. Diversity and Distributions, 15, 338-345. https://doi.org/10.1111/j.1472-4642.2008.00539.x

[116] Johnson, P.T.J., Olden, J.D., Solomon, C.T. and Zanden, M.J.V. (2009) Interactions among Invaders: Community and Ecosystem Effects of Multiple Invasive Species in an Experimental Aquatic System. Oecologia, 159, 161-170.

https://doi.org/10.1007/s00442-008-1176-x 